\title{
Diversity of sandflies (Psychodidae: Phlebotominae) captured in sandstone caves from Central Amazonia, Brazil
}

\author{
Veracilda Ribeiro Alves ${ }^{1 /+}$, Rui Alves de Freitas ${ }^{2}$, Francisco Lima Santos ${ }^{2}$, Toby Vincent Barrett ${ }^{1}$ \\ ${ }^{1}$ Laboratório de Triatominae, Phlebotominae e Fauna Nidicola, Coordenação de Pesquisas em Entomologia \\ 2Laboratório de Leishmanioses, Coordenação de Pesquisas em Ciências da Saúde, Instituto Nacional de Pesquisas da Amazônia, \\ Av. André Araújo 2936, 69083-970 Manaus, AM, Brasil
}

In the present paper we describe the diversity of phlebotomine sandflies collected in three sandstone caves in the municipality of Presidente Figueiredo, state of Amazonas, Brazil. The phlebotomines were captured during 2006 with CDC light traps. Guano samples from inside the Gruta Refúgio do Maruaga were collected to investigate the presence of immature specimens. A total of 2,160 adult phlebotomines representing 15 species were captured. Pintomyia pacae was the dominant species in Gruta dos Animais (1,723 specimens) and Gruta dos Lages (50 specimens) and Deanemyia maruaga new comb (280 specimens) was the dominant species in Gruta Refúgio do Maruaga. A total of 18 guano samples were collected and seven of these samples included immature specimens. A total of 507 immature specimens were captured; 495 of these specimens were larvae and 12 were pupae. The presence of paca (Agouti paca) footprints near Gruta dos Animais and Gruta dos Lages suggests the association of Pi. pacae with this rodent. This finding may explain the abundance of $\mathrm{Pi}$. pacae in these locations, while the species is relatively rare in the forest. Deanemyia maruaga is a cave species that uses guano to breed during its immature stages. Adult specimens of this species are apparently parthenogenetic and autogenous and represent the second record of parthenogenesis for the subfamily Phlebotominae.

Key words: phlebotomine - cave fauna - parthenogenesis - immature - breeding site

Sandflies are small Diptera which can transmit bacteria, viruses and trypanosomatids to humans and animals. The transmission occurs during the bite of female insects. Among the trypanosomatids transmitted, the species of the genus Leishmania Ross, 1903 are responsible for causing visceral and cutaneous leishmaniasis (Rangel \& Lainson 2003). In general, the period of activity of phlebotomine sandflies is from dusk to dawn and these insects remain most of the day at rest in natural shelters (Sherlock 2003).

Caves are places characterized by the absence of light in areas far from the entrance and present stable climate compared to the external environment (Poulson $\&$ White 1969). Fauna adapted to these conditions can be classified according to their level of adaptation: troglobites (animals that present unique modifications to cave environments), troglophiles (adapted animals, but devoid of modifications that can also develop in the external environment) and trogloxenes (animals that use caves for shelter or refuge) (Holsinger \& Culver 1988).

Although caves are apparently inhospitable environments for sandflies, some studies have shown that caves may harbour sandflies (Galati et al. 2003a, b, Alves et al. 2008); occurrence of morphological anomalies (AndradeFilho et al. 2004) shows that insect diversity and density of sandflies in caves can be equal to or greater than those found in the forest (Galati et al. 2003c, 2006).

Financial support: INPA (PPI:1-0705)

+ Corresponding author: verabioufmt@yahoo.com.br

Received 30 November 2010

Accepted 24 March 2011
The municipality of Presidente Figueiredo, state of Amazonas (AM), Brazil, includes areas for ecotourism, such as waterfalls and caves. Among the latter, the Gruta Refúgio do Maruaga and Gruta dos Animais sandstone caves date back thousands of years and are regarded as rare relics of the Palaeozoic Era (Karmann 1986).

The aim of the present work was to study the diversity, period of activity and abundance of phlebotomine sandflies captured in three sandstones caves in the municipality of Presidente Figueiredo.

\section{MATERIAL AND METHODS}

Study area - Presidente Figueiredo municipality, where the caves are found, is located northern of municipality of Manaus at km 107 of BR-174 highway, connecting Manaus to Boa Vista, in state of Roraima. The Gruta Refúgio do Maruaga is located at km 6 of highway AM-240 $\left(02^{\circ} 03^{\prime} 02^{\prime \prime} 49 \mathrm{~S} 59^{\circ} 57^{\prime} 48^{\prime \prime} 85 \mathrm{~W}\right) 600 \mathrm{~m}$ on the right side of the roadway. The cave Gruta dos Animais $\left(02^{\circ} 03^{\prime} 02^{\prime \prime} 64 \mathrm{~S}\right.$ $59^{\circ} 57^{\prime} 51^{\prime \prime} 47 \mathrm{~W}$ ) is near Gruta Refúgio do Maruaga and the Gruta dos Lages (01'59'41"3S $\left.60^{\circ} 01^{\prime} 36^{\prime \prime} 5 \mathrm{~W}\right)$ is located to the left side of $113 \mathrm{~km}$ of BR-174 highway.

Sampling of adults - Samples were collected during 2006 inside the caves with CDC traps placed $10 \mathrm{~m}$ equidistant from each one another, with the first at a distance of $10 \mathrm{~m}$ from the entrance, the traps operated for $48 \mathrm{~h}$ continuously and the samples were collected every $12 \mathrm{~h}$ and separated in night-time (18:00 pm-6:00 am) and day-time (6:00 am-18:00 pm) periods. The period of capture and sampling effort of the sandflies were not the same in all areas due to the distance between Gruta dos Lages and the other caves. Measures of instantaneous temperature and relative humidity were performed us- 
ing a digital thermo-hygrometer (Minipa/MTH-1361). In Gruta dos Animais it was not possible to assess measures of temperature and humidity due to saturation of local humidity. Inside Gruta Refúgio do Maruaga measures were taken at five points, from entrance into the final chambers and the average temperature and humidity were calculated.

The nomenclature of species follows Galati (2003) and the abbreviation of the genera follows Marcondes (2007).

Gruta dos Animais - The specimen collections were conducted during the months of February-April using five traps. The first trap was $10 \mathrm{~m}$ away from the entrance of the cave, the second and third traps were separated by approximately $10 \mathrm{~m}$ and the fourth and fifth traps were at a distance of $80 \mathrm{~m}$ and $120 \mathrm{~m}$, respectively.

Gruta dos Lages - The collection was made in May. Eight traps were randomly distributed during the night (3 nights); luminosity inside the cave prevented the use of the light traps during day-time.

Gruta Refúgio do Maruaga - The collections were made during four months in the period from FebruaryMay. A total of 14 traps (February) and 20 traps (MarchMay) were used, the increase in the number of traps was due to the higher abundance of sandflies at the end of the cave. All captured specimens were identified after clarification process (Young \& Duncan 1994). For Deanemyia maruaga, other techniques were used to clarify and are discussed in Alves et al. (2008), as well as a description of the biology of adults.

Statistical analysis - The frequency of the insects that were captured during the simultaneous periods that occurred during nocturnal or diurnal periods in March, April and May 2006 were obtained using Williams' geometric mean (Haddow 1960). To determine whether there was a significant difference in the distances between the collection points 2-5 in Gruta dos Animais for Pintomyia pacae, between the collection points for De. maruaga, and for periods day-time and night-time in Gruta Refúgio do Maruaga, nonparametric KruskalWallis test were performed by using PAST software, version 1.92 (Hammer et al. 2001).

Sampling of immature - Guano collections were made in 12 points of the guano deposit at the final chambers of the Gruta Refúgio do Maruaga during the months of March-May and September. Each guano sample weighed approximately $300-500 \mathrm{~g}$ of guano. A total of 15 samples from March-May and three from September were taken. The remaining samples were analyzed by flotation technique (Hanson 1961). Larvae and pupae were reared in the laboratory, according to the methods of Killick-Kendrick et al. (1977) with supplementation of the medium with autoclaved guano.

\section{RESULTS}

In Gruta dos Animais, 1,770 specimens were captured and belonged to 12 species, in Gruta Refúgio do Maruaga, 298 specimens of seven species and in Gruta dos Lages, 91 specimens of seven species (Table I).
In Gruta dos Animais, 1,426 and 297 individuals of Pi. pacae were collected during night-time and day-time periods, respectively. At night, the specimens of this species were captured along the entire length of the cave while during the day the insects were collected near the entrance of the cave (Table II). Pi. pacae was the dominant species in both periods.

In Gruta dos Lages, of the 91 specimens captured the most representative species were Pi. pacae (50), Evandromyia georgii (18) and Sciopemyia sordellii (11).

In Gruta Refúgio do Maruaga, 280 specimens were captured and identified as De. maruaga, of which, 176 were collected during night-time and 104 during daytime. During the night, this species was captured along nearly the entire length of the cave. In the day-time, it was only collected before 20 and after $120 \mathrm{~m}$ from the cave entrance (Table III).

The areas of greatest concentration of De. maruaga in Gruta Refúgio do Maruaga were between 120-200 m from the cave entrance, with a higher peak during the night, between 190-200 m, at sites located at the end of the cave. This result is confirmed by comparison between the Williams' geometric mean of the gradient of the absolute frequency in Gruta Refúgio do Maruaga during the simultaneous period of capture between March-May 2006 (Figure).

For Pi. pacae, the Kruskal-Wallis test showed no significant difference for the values between points P2-P5 in Gruta dos Animais $(\mathrm{H}=4.003$, $\mathrm{df}=4, \mathrm{p}=0.406)$. Similarly, the analysis of the distance between sampling points and the day-time and night-time periods in Gruta Refúgio do Maruaga for the species De. maruaga was not significant $(\mathrm{H}=0.1538, \mathrm{df}=4, \mathrm{p}=0.6949)$.

The search for immature sandflies from samples collected in Gruta Refúgio do Maruaga resulted in a total of 507 specimens of which $495(97.6 \%)$ were larvae, mostly at third and fourth instars, and $12(2.4 \%)$ were pupae. Of the 18 samples, seven were positive for immature $D e$. maruaga (39\%). The average time between the recovery of the larvae to adult emergence was approximately 70 days. Approximately 30 adult females were separated in rearing pots to lay eggs. Each female laid an average of eight eggs, but batches of 12 and 23 eggs were also observed. Some eggs were found stranded on the abdomen of the females after laying. The eggs took an average of 21 days to hatch. Approximately $98 \%$ of larvae died during the first 15 days (1st instar). Only one completed the life-cycle from egg to adult in 90 days, in laboratory conditions.

\section{DISCUSSION}

The sandflies species collected in the caves reflect the known fauna of continuous forest in the municipalities of Presidente Figueiredo and Balbina (Barrett 1993), except for De. maruaga. However, Pi. pacae is rarely captured in the forest showing a low frequency in captures with CDC traps (Barrett 1993, Dias-Lima et al. 2003). On the other hand, Pi. pacae was the dominant species in Gruta dos Animais and Gruta dos Lages. This species' presence in these caves might be associated with the presence of paca (Agouti paca), which might act as a 





TABLE II

Phlebotomine captured in Gruta dos Animais, Presidente Figueiredo, Amazonas, Brazil, by collection site in day-time (DT) and night-time (NT) periods from February-April 2006

\begin{tabular}{|c|c|c|c|c|c|c|c|c|c|c|}
\hline \multirow[b]{2}{*}{ Species } & \multicolumn{2}{|c|}{$\mathrm{P} 1$} & \multicolumn{2}{|c|}{$\mathrm{P} 2$} & \multicolumn{2}{|c|}{ P3 } & \multicolumn{2}{|c|}{ P4 } & \multicolumn{2}{|c|}{ P5 } \\
\hline & NT & DT & NT & DT & NT & DT & NT & DT & NT & DT \\
\hline Nyssomyia anduzei & - & - & 1 & - & - & - & 1 & - & - & - \\
\hline Psychodopygus davisi & - & - & - & - & - & - & 1 & - & - & - \\
\hline Psathyromyia cuzquena & 1 & - & - & - & - & - & - & - & - & - \\
\hline Bichromomyia flaviscutellata & 1 & - & - & - & - & - & - & - & - & - \\
\hline Evandromyia inpai & - & - & - & - & - & - & - & - & - & 1 \\
\hline Evandromyia monstruosa & - & - & 3 & - & - & - & - & - & - & - \\
\hline Pintomyia pacae & 1,285 & 297 & 41 & - & 49 & - & 31 & - & 20 & - \\
\hline Evandromyia sericea & - & - & 1 & - & - & - & - & - & - & - \\
\hline Micropygomyia pilosa & - & - & 1 & - & - & - & - & - & - & - \\
\hline Sciopemyia pennyi & 25 & - & 1 & - & - & 1 & - & - & - & - \\
\hline Sciopemyia sordellii & 4 & 1 & 2 & - & - & - & - & - & 1 & - \\
\hline Nyssomyia umbratilis & - & - & 1 & - & - & - & - & - & - & - \\
\hline Total & 1,316 & 298 & 51 & - & 49 & 1 & 33 & - & 21 & 1 \\
\hline
\end{tabular}

distance of the light traps from the mouth Gruta dos Animais: P1: 10 m; P2: 20 m; P3: 30 m; P4: 80 m: P5: 120 m.

TABLE III

Abundance of sandflies species collected in Gruta Refúgio do Maruaga, Presidente Figueiredo, Amazonas, Brazil, during night-time and day-time periods, from February-May 2006

\begin{tabular}{|c|c|c|c|c|c|c|c|c|c|c|c|c|c|}
\hline \multirow[b]{2}{*}{ Species } & & \multicolumn{12}{|c|}{ Distance (m) } \\
\hline & & 10 & 20 & 50 & 120 & 130 & 140 & 150 & 160 & 170 & 180 & 190 & 200 \\
\hline \multirow[t]{7}{*}{ Night-time } & Nyssomyia anduzei & 1 & - & - & 1 & - & - & - & - & - & - & - & - \\
\hline & Bichromomyia flaviscutellata & 1 & 5 & - & - & - & - & - & - & - & - & - & - \\
\hline & Pintomyia pacae & 2 & 1 & - & - & - & - & - & - & - & - & - & - \\
\hline & Micropygomyia pilosa & - & 1 & - & - & - & - & - & - & - & - & - & - \\
\hline & Evandromyia sericea & 1 & - & - & - & - & - & - & - & - & - & - & - \\
\hline & Sciopemyia sordellii & 3 & 2 & - & - & - & - & - & - & - & - & - & - \\
\hline & Deanemyia maruaga & 6 & 4 & 1 & 1 & 2 & 4 & 4 & - & 3 & 5 & 97 & 49 \\
\hline Day-time & Deanemyia maruaga & 2 & - & - & - & 2 & 3 & 2 & 6 & 21 & 10 & 5 & 53 \\
\hline
\end{tabular}

source of food for this sandfly. In the two caves, recent footprints of this rodent were found, suggesting that the rodents use these caves as shelter explaining the abundance of $P i$. pacae in these environments.

De. maruaga is a species restricted to Gruta Refúgio do Maruaga, being the areas of greatest occurrence is $160-200 \mathrm{~m}$ from the cave entrance, where the main deposit of guano and breeding site are also located. A study (Barrett 1993) carried out in this region recorded
68 species of sandflies, but no records of the De. maruaga were found. Furthermore, in three days of night capture in February 2006 outside entrance of the cave, no specimen of De. maruaga was collected implying that it is restricted to the inside in Gruta Refúgio do Maruaga.

De. maruaga is the first sandfly species restricted to caves described from Brazil. Immature and adult specimens collected in this study developed in the aphotic zone of Gruta Refúgio do Maruaga, with a high humid- 


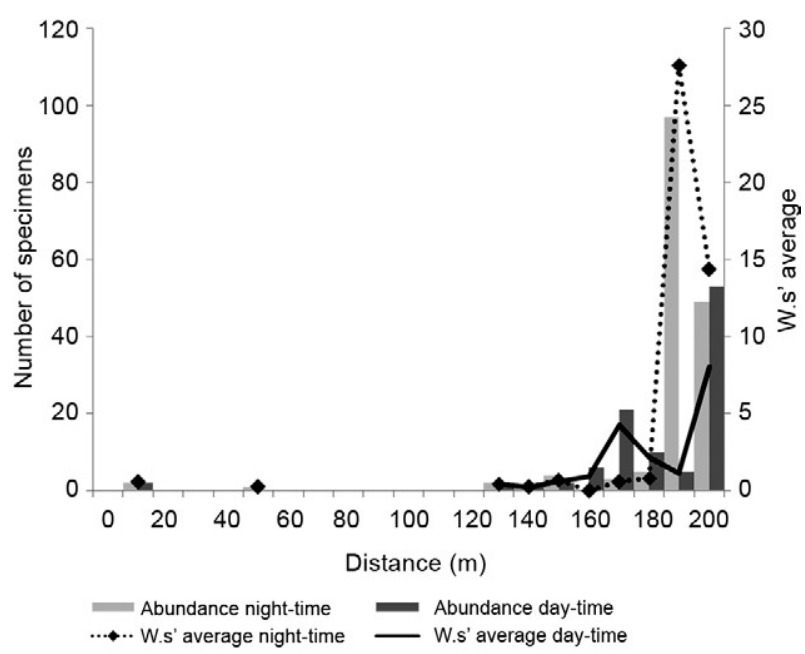

Monthly Williams' (W.s') average and abundance of Deanemyia maruaga captured in Gruta Refúgio do Maruaga, Presidente Figueiredo, Amazonas, Brazil, during day-time and night-time periods in March, April and May 2006.

ity (about 95\%) and an average temperature of $26^{\circ} \mathrm{C}$ and used guano as breeding site. The observation of immature specimens of De. maruaga breeding in guano in Gruta Refúgio do Maruaga results in the first record of a natural breeding site under in this conditions for Brazil. Galati et al. (2003c), who studied sandflies in the Lago Azul cave (state of Mato Grosso do Sul), detected three third instar larvae of Lutzomyia almerioi on the floor of the base of the cave wall suggesting that the breeding site could be found at this location. Most records of breeding sites referred to the bases of trees as potential sites for the development of immature because they are rich in organic matter (Hanson 1961, Sherlock 1962, Feliciangeli 2004). Of the 18 guano samples analyzed, $39 \%$ were positive for immature sandflies; this number being higher than that found by Hanson (1961) in Panama (20.4\%) and by Ghosh and Bhattacharya (1991) in India $(11.45 \%)$. This is probably due to the inherent characteristics of the micro-habitat and specificity of the larva. Thus, the number of immature collected and the frequency of positive samples collected are relevant for establishing the natural breeding site of this species.

De. maruaga has several morphological and physiological peculiarities regarding the egg, larva, adult, and its life cycle. The egg colour is gray, whereas the eggs of other sandfly species are dark coloured (Feliciangeli et al. 1993, Young \& Duncan 1994). This difference in colour may be due to the fact that this species evolved in caves in the aphotic zone with no need for protection from sunlight for the development of the larva. In fact, hours before the eggs hatch the larvae can be observed inside the egg. In the laboratory, the number of eggs per clutch for each female of De. maruaga was variable and was generally between 6-12 eggs; however, there were instances of 23 eggs. Presumably, the reduced number of eggs is caused by artificial rearing and feeding condi- tions. In other species of sandflies, the number of eggs per clutch ranges from 40-70 eggs, depending on various factors, such as the size of the species, the acquisition of a prior blood meal and the diet (Young \& Duncan 1994). The incubation period for the eggs of De. maruaga was approximately 21 days. Young and Duncan (1994) argue that the normal incubation period for sandflies species is approximately 10 days. However, this period may extend up to 30 days or more if the optimal conditions are not present. Brazil and Oliveira (1999) obtained an average of 11 days for the egg development of Pintomyia mamedei and a fecundity of 28 eggs per female. This value was fewer than the values reported by Young and Duncan (1994) but was similar to that for De. maruaga if we consider the number of eggs that are retained in the abdomen, as these eggs would likely develop fully in natural conditions.

The larva has a pair of caudal setae on the first instar and two pairs of setae on the following instars of different lengths. The upper pair of setae is approximately twice the length of the lower, which is a distinct characteristic for the larvae of the known sandfly species that have two pairs of caudal setae of similar size (Young $\&$ Duncan 1994). The sandfly species that were studied in caves in Africa exhibited similar characteristics. For example, Phlebotomus mirabilis, which breeds its immature stages in guano in the deep, dark areas of caves, has a lower pair of long caudal setae that are short in the first instar (Vattier-Bernard 1971a). The pattern of the body setae of the larvae of De. maruaga is also different from that of the other described American species, resembling the setae of Sergentomyia hamoni (Trouillet 1979). In the present study, the first instar larva had a period of development of approximately three weeks, the second, third and fourth instar had a developmental period of approximately 15 days each and the pupa had a developmental period of approximately 15 days. According to Young and Duncan (1994), the length of the larval period of several species of sandflies may depend on the weather conditions (cold or dry) and may range from 18 days to several months. In these species, the pupal period varies from seven to 12 days. Brazil and Oliveira (1999) reported an average of 27.6 days for the larval and pupal stages for Pi. mamedei, with an average of 10.8 days (6-21 days).

The females of De. maruaga have a visible reserve of fat in the abdomen, which is not commonly observed in other sandfly species. A few days ( $\pm 5-6$ days) after the emergence of the adult, the development of eggs and a decrease in the amount of the fat reserves was observed. Many insects do not feed as adults; they depend on fat, protein and glycogen that have been deposited in the fat body during their development. In addition, these glycogen deposits can be quickly mobilised to release glucose in response to hormones (Rupert et al. 2005).

Autogeny has been observed in several species of Culicidae (O'Meara \& Kranisck 1970, O'Meara \& Evans 1977), Tabanidae (Charlwood \& Rafael 1980) and sandflies (Feliciangeli et al. 1993, Brazil \& Oliveira 1999). This is a phenomenon that occurs in haematophagous 
insects that allows for the development of eggs without a prior blood meal, depending on the insect's diet during the larval period (O’Meara \& Kranisck 1970, Perondini et al. 1975). The autogenic behaviour observed in De. maruaga may be explained by the fact that guano is rich in nutrients, enabling the larva to feed adequately and to produce fat reserves that are sufficient to maintain the adult and to enable reproduction.

De. maruaga presented a life span that exceeded 90 days in the laboratory. For another species of sandfly, Nyssomyia umbratilis, Justiniano et al. (2004) obtained an average of 77 days for this species' life cycle from two populations in AM. However, the life cycle of other Neotropical species ranged from 34-54 days (Sherlock \& Sherlock 1959, Killick-Kendrick et al. 1977, Ward 1977, Ferro et al. 1998, Brazil \& Oliveira 1999). For P. mirabi$l i s$, an African cave species, the average life cycle duration was 110.6 days in the laboratory that was erected inside of the cave, which is lower than the average that was obtained from the colony of wild females (133.7) (Vattier-Bernard 1971a). This author also suggests that the life cycle is longer in authentic cave species (troglobites) than in other species (Vattier-Bernard 1971b). The environment in which $P$. mirabilis was found has abiotic characteristics (temperature of approximately $25^{\circ} \mathrm{C}$ and relative humidity between $96-100 \%$ ) that are similar to the natural habitat of De. maruaga.

The findings about the breeding site of De. maruaga, this species' life cycle inside the Gruta Refúgio do Maruaga and the morphological and physiological changes of this species indicate that this specimen can be classified as a troglobite. There is no known record of other Neotropical sandfly species with their life cycle restricted to the inside of a cave. The development of eggs in the absence of males and without a prior blood meal in this species is the second record of parthenogenesis in conjunction with autogeny within the subfamily Phlebotominae; the first instance was described by Brazil and Oliveira (1999) for Pi. mamedei.

\section{ACKNOWLEDGEMENTS}

To Paloma HF Shimabukuro, for valuable comments, to Walter S Santos and Márcio LL Barbosa, by their suggestions on the tables and figure, to Alex Sandro B Souza, for help with statistical analysis, and to anonymous reviewers, by their suggestions.

\section{REFERENCES}

Alves VR, Freitas RA, Barrett T 2008. Lutzomyia maruaga (Diptera: Psychodidae), a new bat-cave sand fly from Amazonas, Brazil. Mem Inst Oswaldo Cruz 103: 251-253.

Andrade-Filho JD, Carvalho GML, Saraiva L 2004. Bilateral anomaly in the style of Micropygomyia schreiberi (Martins, Falcão \& Silva) (Diptera, Psychodidae). Rev Bras Entomol 48: 583-585.

Barrett TV 1993. Cutaneous leishmaniasis in Amazonas state, Brazil: ecoepidemiology and questions of control, Proceedings of National Workshop Research and Control of Leismaniasis in Brazil, Recife, p. 31-44.

Brazil RP, Oliveira SM 1999. Parthenogenesis in the sandfly Lutzomyia mamedei (Diptera: Psychodidae). Med Vet Entomol 13: 463-464.

Charlwood JD, Rafael JA 1980. Autogeny in the river Negro horse fly, Lepiselaga crassipes, and an undescribed species of Steno- tabanus (Diptera, Tabanidae) from Amazonas, Brazil. J Med Entomol 17: 519-521.

Dias-Lima AG, Castellón EG, Sherlock I 2003. Flebotomíneos (Diptera: Psychodidae) de uma floresta primária de terra firme da Estação Experimental de Silvicultura Tropical, estado do Amazonas, Brasil. Acta Amazonica 33: 303-316.

Feliciangeli MD 2004. Natural breeding places of phlebotomine sandflies. Med Vet Entomol 18: 71-80.

Feliciangeli MD, Castejon OC, Limongi J 1993. Egg surface ultrastructure of eight New World phlebotomine sand fly species (Diptera: Psychodidae). J Med Entomol 30: 651-656.

Ferro C, Cárdenas E, Corredor D, Morales A, Munstermann LE 1998. Life cycle and fecundity analysis of Lutzomyia shannoni (Dyar) (Diptera: Psychodidae). Mem Inst Oswaldo Cruz 93: 195-199.

Galati EAB 2003. Morfologia e taxonomia. Classificação de Phlebotominae. In EF Rangel, R Lainson (org.), 1st ed., Flebotomíneos do Brasil, Fiocruz, Rio de Janeiro, p. 23-51.

Galati EAB, Andrade-Filho JD, Silva ACL, Falcão AL 2003a. Description of a new genus and new species of New World Phlebotominae (Diptera, Psychodidae). Rev Bras Entomol 47: 63-70.

Galati EAB, Marassá AM, Andrade RMG 2003b. Micropygomyia (Sauromyia) petari, a new species of Phlebotominae (Diptera: Psychodidae) from Vale do Ribeira, São Paulo state, Brazil. Rev Bras Entomol 47: 455-459.

Galati EAB, Nunes VLB, Boggiani PC, Dorval MEC, Cristaldo G, Rocha HC, Oshiro ET, Dasmaceno-Júnior GA 2006. Phlebotomines (Diptera: Psychodidae) in forested areas of the Serra da Bodoquena, state of Mato Grosso do Sul, Brazil. Mem Inst Oswaldo Cruz 101: 175-193.

Galati EAB, Nunes VLB, Boggiani PC, Dorval MEC, Cristaldo G, Rocha HC, Oshiro ET, Gonçalves-de-Andrade RM, Naufel G 2003c. Phlebotomines (Diptera: Psychodidae) in caves of the Serra da Bodoquena, Mato Grosso do Sul State, Brazil. Rev Bras Entomol 47: 283-296.

Ghosh KN, Bhattacharya A 1991. Breeding places of Phlebotomus argentipes Annandale and Brunetti (Diptera: Psychodidae) in West Bengal, India. Parassitologia 33 (Suppl. 1): 267-272.

Haddow AJ 1960. Studies on the biting habits and medical importance of East African mosquitos in the genus Aedes. I. Subgenera Aedimorphus, Banksinella and Dunnius. Bull Entomol Res 50: 759-779.

Hammer O, Harper DAT, Ryan PD 2001. PAST: Paleontological statistics software package for education and data analysis. Paleont Eletron 4: 9.

Hanson WJ 1961. The breeding places of Phlebotomus in Panama (Diptera: Psychodidae). Ann Entomol Soc Am 54: 317-322.

Holsinger JR, Culver DC 1988. The invertebrate cave fauna of Virginia USA and a part of eastern Tennessee zoogeography and ecology. Brimleyana 14: 1-162.

Justiniano SC, Chagas AC, Pessoa FA, Queiroz RG 2004. Comparative biology of two populations of Lutzomyia umbratilis (Diptera: Psychodidae) of Central Amazonia, Brazil, under laboratory conditions. Braz J Biol 64: 227-235.

Karmann I 1986. Caracterização geral e aspectos genéticos da gruta arenítica Refúgio do Maroaga, AM-02. Espeleo-Tema 15: 9-18.

Killick-Kendrick R, Leaney AJ, Ready PD 1977. The establishment, maintenance and productivity of a laboratory colony of Lutzomyia longipalpis (Diptera: Psychodidae). J Med Entomol 13: 429-440.

Marcondes CB 2007. A proposal of generic and subgeneric abbreviations for phlebotomine sandflies (Diptera: Psychodidae: Phlebotominae) of the world. Entomol News 118: 351-356. 
O'Meara GF, Evans DC 1977. Autogeny in saltmarsh mosquitoes induced by a substance from the male accessory gland. Nature 267: 342-344.

O'Meara GF, Kranisck GJ 1970. Dietary and genetic control of the expression of autogenous reproduction in Aedes atropalpus (Coq.) (Diptera: Culicidae). J Med Entomol 7: 328-334.

Perondini ALP, Costa MJ, Brasileiro VLF 1975. Biologia do Triatoma brasiliensis. II. Observações sobre a autogenia. Rev Saude Publica 9: 363-370.

Poulson TL, White WB 1969. The cave environment. Science 165: 971-981.

Rangel EF, Lainson R 2003. Flebotomíneos do Brasil, Fiocruz, Rio de Janeiro, 367 pp.

Rupert EE, Barnes RD, Fox RS 2005. Zoologia dos invertebrados: uma abordagem funcional-evolutiva, 7th ed., Roca, São Paulo, 1145 pp.

Sherlock IA 1962. Nota sobre criadouros naturais de Phlebotomus em Salvador, Bahia (Diptera, Psychodidae). Rev Bras Biol 22: 125-157.

Sherlock IA 2003. Importância médico-veterinária. A importância dos flebotomíneos. In EF Rangel, R Lainson (orgs.), Flebotomíneos do Brasil, Fiocruz, Rio de Janeiro, p. 15-21.
Sherlock IA, Sherlock VA 1959. Criação e biologia em laboratório do Phlebotomus longipalpis (Lutz \& Neiva, 1912). Rev Bras Biol 19: $229-250$.

Trouillet J 1979. Sergentomyia (Rondanomyia) ingrami Newstead, 1914, Sergentomyia (Rondanomyia) dureni Parrot, 1934 e Sergentomyia hamoni Abonnenc, 1958 (Diptera, Phlebotomidae). Étude morphologique des stades préimaginaux et notes bioécologiques. Ann Parasitol 54: 353-373.

Vattier-Bernard G 1971a. Étude morphologique et biologique des phlébotomes cavernicoles du Congo Brazzaville. Ann Spéléol 26: $149-171$.

Vattier-Bernard G 1971b. Notes sur la biologie de deux espèces de phlébotomes cavernicoles africains. Bull Soc Ecol 2: 293-301.

Ward RD 1977. The colonization of Lutzomyia flaviscutellata (Diptera: Psychodidae), a vector of Leishmania mexicana amazonensis in Brazil. J Med Entomol 14: 469-476.

Young DG, Duncan MA 1994. Guide to the identification and geographic distribution of Lutzomyia sand flies in Mexico, the West Indies, Central and South America (Diptera: Psychodidae). Mem Am Entomol Institute 54: 1-881. 